the footnotes). Perhaps greater attention should have been paid to secondary sources wherever primary sources were unavailable (such as many pertinent publications of the Bulgarian Academy's Institute of History). And some names are misspelled (Pancho Hadjimisheff, not Pontcho Hadji Misheff). Yet, there should be no doubt at all about the author's scholarship and contribution.

L. A. D. DeLlin

University of Vermont

\title{
MAGYAR-CSEHSZLOVÁK KAPCSOLATOK 1918-1921-BEN. By Ferenc Boros. Budapest: Akadémiai Kiadó, 1970. 330 pp. 47 Ft.
}

Ferenc Boros is a brave man who has undertaken to investigate a delicate topic. Today the Czechoslovak Socialist Republic and the Hungarian People's Republic not only consider one another fellow socialist countries, but are on the best of terms. In the period examined by Boros relations between the two countries were at their worst. Czechoslovakia had just arisen from the ruins of the Monarchy and included, with the sanction of the Entente, areas inhabited solely by Magyars. The peace treaty of Trianon, writes Boros, was an integral part of the "imperialist system at Versailles" (p. 183) and it "legalized new injustices and set the smoldering fires of new conflicts" (p. 184). It may be noted that the treaties signed in Paris after the Second World War did not redress these injustices, if injustices they were; the border between Czechoslovakia and Hungary remained unchanged, except for a few additional square miles awarded Czechoslovakia near Bratislava. Is then Boros himself fanning the flames of one of those smoldering fires? Not exactly; for the conflict he discusses was between bourgeois Czechoslovakia on the one hand, and the Hungarian Republic of Councils and the counterrevolutionary Horthy regime on the other.

Diplomatic relations are not the main topic of the book; in fact, the word used in the title is "contacts" rather than "relations." The author is primarily interested in the contacts between the workers' movements in the two countries, the subject of his doctoral dissertation at the University of Budapest in 1962. Considerable space is devoted to discussions of articles appearing in the left-wing press (as far as Hungarian papers are concerned, published mostly in Vienna) and to the conflicts between the various factions of the Left among the Czechs and among the Slovaks, as well as among the Hungarian exiles who found refuge in Czechoslovakia or in Austria after the fall of the Republic of Councils. There is little concern with the reality of power, or with the attitude of the average workingman (whether in Hungary, Slovakia, or Czechoslovakia) who fell prey to nationalist sentiments, however bourgeois those may have been. Although the doctoral dissertation has been considerably reduced ( $\mathrm{I}$ am told), I still found the book unnecessarily long.

Nevertheless, the work is not only a brave one, but also an important one. It uses hitherto unused sources, particularly the Czech press and the $C z e c h$ archives of the period. It is a work highly critical of both Hungarian and Czech (he writes "Czechoslovak") nationalism, of Czech imperialism, and of the "machinations" of the Entente powers (p. 8). Even if the contacts between the working class of the two nation-states were not close or particularly significant, Boros provides evidence to show that it is not true that Czechs and Hungarians "were created by God, or moulded by history, to hate one another," as Paul Ignotus wrote ("Czechs, Magyars, 
Slovaks," Political Quarterly, April-June 1969). This work by Boros can be interpreted as an attempt to bring to light and eradicate the roots of resentment.

\section{Mario D. Fenyo \\ Universidad Católica de Puerto Rico}

\section{SAMANÁTORISMUL. By Z. Ornea. Bucharest: Editura Minerva, 1970. 398 pp. Lei 13.}

The word Sămănătorism (from the Rumanian for "sower") describes a current of ideas that achieved a brief and controversial ascendancy in Rumanian intellectual circles during the first decade of this century. It has already been the subject of several important studies, notably Eugen Lovinescu's Istoria miscării "Sămănătorului" (1925) and Dumitru Micu's critique in his Literatura romînă la inceputul secolului al XX-lea (1964), but none of these works analyze its origins and varied manifestations with such comprehensiveness and objectivity as the present book.

$Z$. Ornea views Sămănătorism as the most characteristic response of Rumanian intellectuals between 1895 and 1910 to the two vital issues of the day: the nationality problem in Transylvania and the agrarian crisis at home. The solution it proposed for both was primarily a cultural one-that is, a reaffirmation of traditional national values in political and economic organization and literature and art. Culture, the sămănătorişti claimed, would both thwart Magyarization in Transylvania and end ignorance and misery among the peasantry. The central figure of the movementthe person who more than anyone else, in Ornea's view, created Sămănătorism-was that imposing polymath, Nicolae Iorga. It was he who gave form to nebulous theories and instilled a sense of mission in their authors.

Ornea first surveys the history of the movement and then analyzes it as a current of ideas and describes its contributions to political life, literature, and aesthetics. Its essence he discovers in its romantic-agrarian view of Rumania's development. The source of national virtue, the sămănătorişti held, had always been the village with its benevolent native boier class and hard-working and devout peasantry; but, they lamented, this idyllic existence had been gradually eroded by the assimilation of an alien, cosmopolitan culture and the importation of Western capitalism. Yet it is true that however deeply they yearned for the return of a patriarchal society, Iorga and his colleagues recognized the impossibility of returning to the past and reversing the trend of urbanization and industrialization. This acceptance of reality, Ornea suggests, may have contributed to Sămănătorism's decline, for in essence it proposed nothing. It glorified the rustic and deplored its passing, but at the same time accepted the inevitability of the process.

The author carefully places Sămănătorism in its proper position in the evolution of Rumanian social thought. He does so by describing its antecedents, the conditions prevailing in Rumania at the turn of the century, and the reaction to the movement led by aestheticians like Ovid Densusianu, the champion of symbolism, and literary critics and sociologists like G. Ibrăileanu and Henric Sanielevici, who argued that Rumania could not avoid the processes of modernization.

Ornea has based his monograph on his own reading of the vast literature of and about Sămănătorism and has approached his subject from fresh vantage points. As a result, he has produced a fundamental work for those who seek to understand twentieth-century Rumania.

KerTh Hitchins

University of Illinois, Urbana 